\title{
Corixa lacustris Macan a synonym of C. dorsalis Leach
}

\author{
T. T. MACAN
}

MACaN (1954), after a visit to Denmark, concluded that the species known there as Corixa striata (L.) was not the same as the species known under that name in the British Isles. The Linnean type material being unsatisfactory, he applied the name striata (L.) to the species represented by the Danish specimens, since they agreed with the first modern description of Corixa striata (L.), that of JACZEWSKI (1924), and for the apparently new British species he created the name C. lacustris. Though no description of the differences between the two species had been made before, the new name has proved to be unnecessary. In 1817 LEACH described Corixa dorsalis, the type of which was later lost. However, when Dr. JACZEwSKI visited the British Museum, he examined the collection of STEPHENS, who was contemporary with $\mathrm{LEACH}$, and found in it many specimens with LEACH's names, among them $C$. dorsalis.

This was regarded as a synonym of $C$. striata LinnaEus (China, 1938). I overlooked this paper when naming C. lacustris and the error did not come to light till Dr. CHINA was putting my supposed type specimen into the British Museum collection. Then it occurred to him that it was probably identical with $C$. dorsalis LEACH of which, he tells me, JACZEWSKI, in effect selected a neotype". An examination soon revealed that this specimen agreed with lacustris rather than striata (L.). The synonymy is therefore:

Corixa dorsalis LEACH 1817

Sigara striata ChINa 1938 not (Linnaeus 1758)

Corixa lacustris MACAN 1954

\section{RE FEREN CES}

CHINA, W. E. - 1938. Notes on the nomenclature of British Corixidae. Ent. mon. Mag. 74: 34-38.

JACZewski, T. - I924. Revision of the Polish Corixidae. Ann. zool. Mus. polon. 3: $\mathrm{I}-98$.

LEACH, W. E. - I817. Trans. Linn. Soc. Lond. 12: 17.

MaCAN, T. T. - I954. The Corixidae (Hemipt.) of some Danish Lakes. Hydrobiologia. 6: 44-69. 